\title{
Subcutaneous Emphysema and Inflammation of the Neck after Tracheal Puncture by an Intubating Stylet
}

\author{
Gul Jung, Woo Mok Byun*, Hyung Jun Lim ${ }^{\dagger}$, Jong Gyun Kim, Dong Min Kwak, \\ Deok Hee Lee, Sae Yeon Kim, Sun Ok Song, Il Sook Seo, Dae Lim Jee, \\ Heung Dae Kim, Dae Pal Park \\ Department of Anesthesiology and Pain Medicine, and *Department of Radiology, \\ College of Medicine, Yeungnam University Medical Center, Daegu, Korea \\ ${ }^{\dagger}$ Gyeongsang Hospital, Gyeongsan, Gyeongbuk, Korea
}

\begin{abstract}
- Abstract-
Laryngo-tracheal perforation caused by the use of a stylet during tracheal intubation is a rare complication. We present a case of subcutaneous emphysema and connective tissue inflammation after tracheal intubation. The patient was a 41-year-old male undergoing general anesthesia for an appendectomy. The intubation was difficult during laryngoscopy (Cormack- Lehane Grade III). An assistant provided an endotracheal tube with a stylet inside while the laryngoscope was in place. During intubation, a short, dull sound was heard with a sudden loss of resistance after the distal tip of the endotracheal tube passed the rima glottis. A sonogram and computerized tomography revealed subcutaneous emphysema from the neck to the upper mediastinum and fluid collection between the trachea and the thyroid. This lesion appeared to have been caused by the protruded, loose stylet. Anesthesiologists should be aware of the damage a loose stylet protruding beyond the tip of the endotracheal tube can cause.
\end{abstract}

Key Words: Tracheal Injury, Intubation, Subcutaneous Emphysema

Introduction

Tracheal injuries leading to perforation or rupture are rare. However, they can lead to serious complications. ${ }^{1)}$ The trachea may be injured by multiple attempts at intubation, an

책임저자 : 지대림, 대구광역시 남구 대명5동 317-1, 영남대학교 의과대학 마취통증의학교실

Tel: (053) 620-3367, Fax: (053) 626-5275, E-mail: djee@med.yu.ac.kr 
- Subcutaneous Emphysema and Inflammation of the Neck after Tracheal Puncture by an Intubating Stylet -

intubating stylet, an overdistended cuff, or forceful coughing during intubation., ${ }^{2,5)}$ A large postmortem series following emergency intubation showed that $18 \%$ of cases were affected by tracheal injuries., ${ }^{2,4}$ Surgical repair is usually required in most cases with symptoms, but conservative treatment is also an option in asymptomatic patients without respiratory distress. ${ }^{1-13)}$

We report the case of a 41-year-old male patient of average weight with a tracheal lesion caused by a stylet. The unusual and confusing symptoms of inflammation started to develop one full day after the intubation. A loose stylet should never be tolerated during intubation, as it can go beyond the tip of the tube, causing minor complications such as subcutaneous emphysema or major complications with dyspnea leading to life threatening conditions.

\section{Case Report}

A 41 year-old, American Society of Anesthesiologists (ASA) physical status I male patient with a periappendiceal abscess was to undergo general anesthesia for appendectomy at a private hospital. A Macintosh bladed laryngoscope was used in order to visualize the airway, which was Cormack-Lehane grade III. The anesthesiologist requested the assistant to provide an endotracheal tube with a stylet inside. While keeping an eye on the airway, the anesthetist noticed protrusion of a loose stylet beyond the tip of the tube, but decided to proceed with the intubation. The intubation was successfully performed on a single attempt, during which a short, dull sound was heard with a sudden loss of resistance. The stylet was removed right away, and the tube was advanced until the balloon was in place and inflated. The operation ended uneventfully.

The next day, the patient started to complain of symptoms of swelling, pain, erythema, tenderness, localized heat sensation and a foreign body sensation in the throat. Thyroid function testing was done to exclude thyroiditis, and the consulted otorhinolaryngologist found no visible lesion within the oro- $^{-}$and hypopharynx. Next, a thyroid ultrasonography was performed, which revealed a $3 \mathrm{~cm} \times 1.5$ $\mathrm{cm}$ sized lesion with multiple echogenic and hypoechoic foci between the right lobe of the thyroid gland and the cartilagenous trachea (Fig. 1). The thyroid was compressed outward and away from the trachea by the extrinsic lesion of which the possibility of an abscess formation could not be excluded. The second day after the operation, the thyroid function test results showed normal levels and thyroiditis was excluded as the cause of the patients symptoms, which were now more intense, and with a mild fever. A computerized tomography revealed the formation of subcutaneous emphysema extending from the thyroid to the upper end of the mediastinum, and between the trachea and thyroid (Fig. 
- Gul Jung, Woo Mok Byun, Hyung Jun Lim, Jong Gyun Kim, Dong Min Kwak, Deok Hee Lee,

Sae Yeon Kim, Sun Ok Song, Il Sook Seo, Dae Lim Jee, Heung Dae Kim, Dae Pal Park -

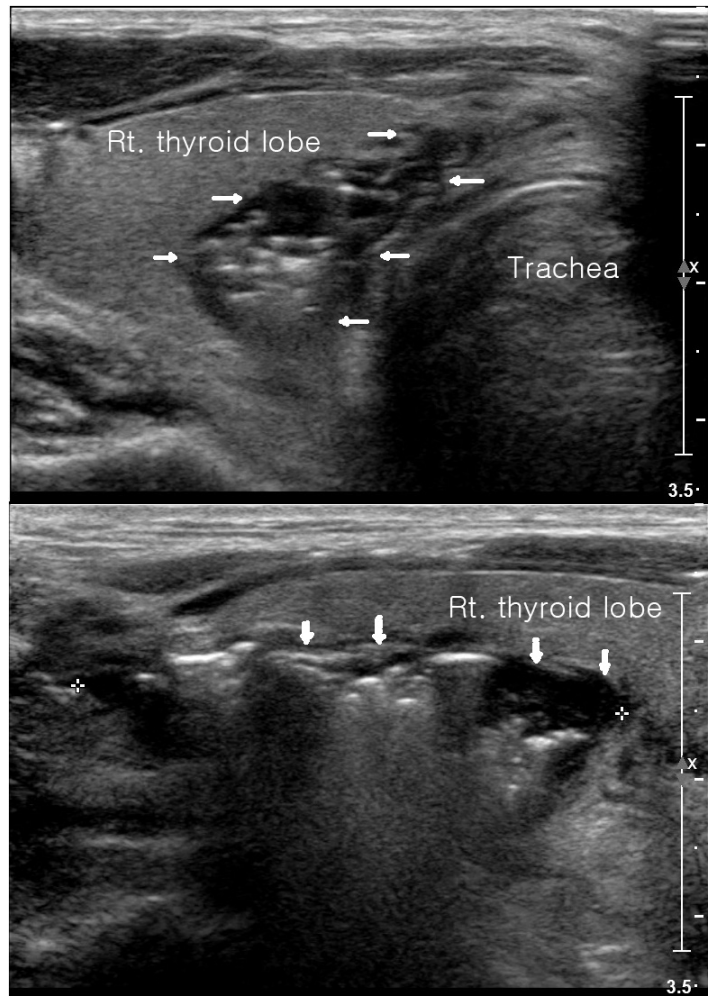

Fig. 1. Arrows point towards the lesion in the thyroid ultrasonography showing expansion, pushing the rt. thyroid lobe laterally away from the trachea (upper), and anteriorly to the skin (lower).

2). The subcutaneous emphysema contained fluid with air bubbles inside. All evidence led to the point of intubation, when the short dull sound and sudden loss of resistance was noticed. The loosely-protruded stylet had caused a perforation of the trachea, through which air and fluid had passed. Broad spectrum antibiotics were added to the usual antibiotics given to appendectomy patients with a suspicion that this lesion was the source of infection. On the fourth day, the fever had subsided, as well as the

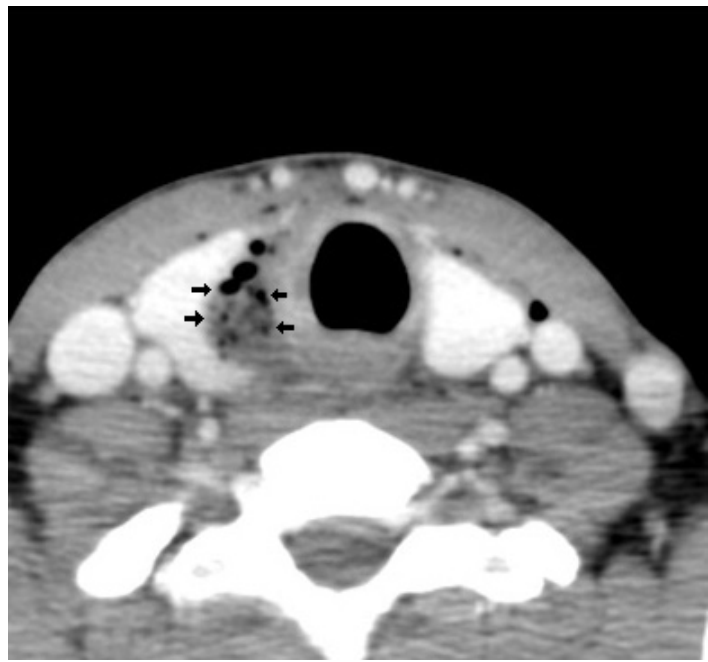

Fig. 2. The CT of the neck showing air and fluid collections between the thyroid and the trachea (arrows pointing towards the lesion).

foreign body sensation, swelling and pain. On the sixth day, a follow ${ }^{-}$up computerized tomography showed complete absorption of the fluid within the emphysema that was now almost fully regressed. The patient was discharged two days later.

\section{Discussion}

Tracheal injuries are potentially lifethreatening complications. These injuries usually occur in patients with a weaknesses in the tracheobronchial area. ${ }^{6-8)}$ Patient risk factors involve weakening of the trachea, such as corticosteroid therapy, chronic obstructive pulmonary disease, advanced age, and mediastinal lymph-node metastasis., 6, 9) The anatomy of the patient's larynx may play a role, in which a difficult intubation 
- Subcutaneous Emphysema and Inflammation of the Neck after Tracheal Puncture by an Intubating Stylet -

may lead to the use of a stylet, and multiple intubation attempts increase the risk of injury. ${ }^{2)}$ The urgency of the intubation may also be a factor an emergency intubation of a non-sedated patient will cause coughing and vigorous forceful attempts at intubation are generally needed compared to an elective general anesthesia setting, where the patient is truly sedated and muscle relaxants are used. In our case, the intubation was performed on ahealthy middle-aged male patient with an ASA physical status I, who had an intact trachea with no past medical history of airway disease. Intubation was successful on a single attempt, thus the only problem was that the stylet protruded past the tip of the beveled endotracheal tube during intubation, which should not be positioned beyond Murphy's eye.

On physical examination, hypopharynx and the visibleparts of the subglottic area were intact. Tracheal injuries almost always occur at the posterior membranous wall, $6,10,11$ ) because the $\mathrm{c}^{-}$-shaped cartilagenous anterior and lateral walls provide reinforcement. However, in our case we speculate that a puncture of the trachea occurred at this cartilagenous portion because it is highly unlikely that the stylet reversed its course posteriorly and injured the posterior wall. We believe that the anterior or lateral trachea had been punctured, because a short and dull sound with a sudden loss of resistance was noted, much like piercing a sturdy hollow cylinder. Recently, a case was reported with a tracheal injury during nasotracheal intubation with a fibroscope, where the second to fourth tracheal cartilages were ruptured this supports our opinion that indeed the cartilagenous portion of the trachea can be perforated during intubation. ${ }^{12)}$

The usual symptoms and complications of tracheal injuries are dyspnea and subcutaneous emphysema. Our patient's perforated trachea had not been diagnosed at first because of the confounding symptoms of erythema, localized heat sensation, pain, and tenderness, which were more suggestive of a traumatic injury to the hypopharynx. No visible lesion was found in the oro- $^{-}$and hypo-pharynx during the laryngology examination, so the possibility of hypopharyngeal injury was excluded. Such injuries have the additional symptoms of odynophagia and infectious complications such as a retropharyngeal abscess and pyrexia, similar to our patient's symptoms. The fever that developed on the next day contributed to the complexity of the diagnosis. The possibility of inflammation could not be excluded because a fluid collection within an emphysematous injury near the thyroid has not been reported previously with tracheal injuries.

Although there was a short and dull sound with a sudden loss of resistance during the intubation, the anesthesiologist was oblivious to the possibility of the stylet piercing the trachea. The possibility of De Quervain's 
- Gul Jung, Woo Mok Byun, Hyung Jun Lim, Jong Gyun Kim, Dong Min Kwak, Deok Hee Lee,

Sae Yeon Kim, Sun Ok Song, Il Sook Seo, Dae Lim Jee, Heung Dae Kim, Dae Pal Park -

thyroiditis (also called subacute thyroiditis, or granulomatous thyroiditis), was evaluated first, which is sometimes caused by a viral infection and is rapidly progressive, causing fever and painful swelling, which resembles infection of the thyroid gland. An infectious origin was also a possibility, but the patient was being treated with the routine antibiotic therapy used for an appendectomy, and the source of infection was unclear. Only after the confirmation of the subcutaneous emphysema, by computerized tomography, did the anesthesiologist realize the meaning of the sounds appreciated during the intubation. All evidence gradually pointed to a perforation of the trachea (through which air and small amounts of fluid had passed and caused inflammatory reactions within the neck) even though perforation of the trachea causing such inflammatory reactions have not been previously reported.

Most patients with a rupture larger than 4 $\mathrm{cm}$ have symptoms related to dyspnea. These patients are usually in need of immediate intervention such as intubation and surgical repair because of respiratory distress ${ }^{5,8)}$, whereas patients with injuries smaller than $4 \mathrm{~cm}$ have delayed, less severe symptoms. ${ }^{50}$ (10) Considering our patient's symptoms, we concluded that the patient did not require urgent surgical repair. Many reports suggest that large injuries almost always heal with perfect scarring without sequelae or stenosis, even in patients with large ruptures whose general condition precluded surgical repair. ${ }^{5}$ ) A recent report of a case by Mullan and colleagues proposed a nonsurgical treatment approach even in patients with major tracheal ruptures. ${ }^{13)}$ Therefore, conservative treatment of our patient was a reasonable treatment option.

Concern still exists that we may have missed an injury to the hypopharynx, consistent with most of the symptoms of our patient. On account of the fluid formation within the subcutaneous emphysema, a rupture such as a small puncture of the pyriform sinus may have been overlooked if the size was significantly small enough. This would explain the fluid content within the subcutaneous emphysema more easily, since secretions are abundant and swallowing induces passage. There is still a possibility that strenuous coughing may have forced tracheal secretions to gush through the punctured area of the trachea. A culture study or an amylase level test of this fluid content might have been helpful in diagnosing whether the hypopharynx or the trachea had been ruptured without the aid of a fibroscope. Even with a fibroscope, it would be hard to see a puncture the size of the diameter of the stylet and situated near the vocal cords.

In conclusion, our patient's trachea, while having no particular risk factors except a Cormack-Lehane Grade III, was perforated by a protruded, loose stylet, which should 
- Subcutaneous Emphysema and Inflammation of the Neck after Tracheal Puncture by an Intubating Stylet -

never be overlooked; especially if it can advance beyond the tip of the endotracheal tube. We recommend that anesthesiologists need to be wary of a loose stylet and recheck that it does not pass further beyond Murphy's eye before intubation.

\section{요 약}

한 41세 남자 환자가 충수돌기염 절제술을 받기 위하여 전신마취를 받았다. 삽관을 위해 후두경으로 보자, 난해한 기도삽관이 예상되어 유도자를 사용하였다. 기도삽관 중 돌출된 유 도자가 기도를 손상시켰으며, 이에 의해 목에 서부터 상부종격동까지의 피하기종과 목의 염 증성 종창이 생겼다. 환자는 호흡곤란과 관련 된 증상을 보이지 않아 호흡기의 손상을 의심 하기 어려웠고, 주 증상이었던 염증성 종창에 초점을 두게 되어 진단에 차질을 빚었으나, 환 자는 대증치료로 회복하였다. 유도자를 사용하 여 기관내 삽관을 하는 경우 유도자의 위치를 재점검하여 유도자에 의한 기도 손상을 유발하 지 않도록 유념해야 할 것이다.

\section{References}

1. Schneider T, Storz K, Dienemann H, Hoffmann $\mathrm{H}$. Management of iatrogenic tracheobronchial injuries: a retrospective analysis of 29 cases. Ann Thorac Surg 2007 Jun;83(6):1960-4.

2. Moschini V, Losappio S, Dabrowska D, Iorno V. Tracheal rupture after tracheal intubation: effectiveness of conservative treatment. Minerva Anestesiol 2006 Dec;72(12):1007-12.

3. Fan CM, Ko PC, Tsai KC, Chiang WC, Chang
YC, Chen WJ, Yuan A. Tracheal rupture complicating emergent endotracheal intubation. Am J Emerg Med 2004 Jul;22(4):289-93.

4. Striebel HW, Pinkwart LU, Karavias T. Tracheal rupture caused by overinflation of endotracheal tube cuff. Anaesthesist 1995 Mar; 44(3):186-8.

5. Jougon J, Ballester M, Choukroun E, Dubrez J, Reboul G, Velly JF. Conservative treatment for postintubation tracheobronchial rupture. Ann Thorac Surg 2000 Jan;69(1):216-20.

6. Marty-Ane $\mathrm{CH}$, Picard E, Jonquet O, Mary H. Membranous tracheal rupture after endotracheal intubation. Ann Thorac Surg 1995 Nov;60(5): 1367-71.

7. Harris R, Joseph A. Acute tracheal rupture related to endotracheal intubation: case report. J Emerg Med 2000 Jan;18(1):35-9.

8. Fan CM, Ko PC, Tsai KC, Chiang WC, Chang $\mathrm{YC}$, Chen WJ, et al. Tracheal rupture complicating emergent endotracheal intubation. Am J Emerg Med 2004 Jul;22(4):289-93.

9. Zettl R, Waydhas C, Biberthaler P, Lewan U, Riedl V, Duswald $\mathrm{KH}$, et al. Nonsurgical treatment of a severe tracheal rupture after endotracheal intubation. Crit Care Med 1999 Mar;27(3):661-3.

10. Kaloud H, Smolle-Juettner FM, Prause G, List WF. Iatrogenic ruptures of the tracheobronchial tree. Chest 1997 Sep;112(3):774-8.

11. Hofmann HS, Rettig G, Radke J, Neef H, Silber RE. Iatrogenic ruptures of the tracheobronchial tree. Eur J Cardiothorac Surg 2002 Apr;21(4):649-52.

12. Kaneko Y, Nakazawa K, Yokoyama K, Ishikawa S, Uchida T, Takahashi M, et al. Subcutaneous emphysema and pneumomediastinum after translaryngeal intubation: tracheal perforation due to unsuccessful fiberoptic tracheal intubation. J Clin Anesth 2006 Mar;18(2):135-7. 
- Gul Jung, Woo Mok Byun, Hyung Jun Lim, Jong Gyun Kim, Dong Min Kwak, Deok Hee Lee, Sae Yeon Kim, Sun Ok Song, Il Sook Seo, Dae Lim Jee, Heung Dae Kim, Dae Pal Park -

13. Mullan GP, Georgalas C, Arora A, Narula A. management. Eur Arch Otorhinolaryngol 2007 Conservative management of a major post- Jun;264(6):685-8. intubation tracheal injury and review of current 